\title{
Comparison of genetic alterations in neuroendocrine tumors: frequent loss of chromosome 18 in ileal carcinoid tumors
}

\author{
Gordon G Wang ${ }^{1}$, James C Yao ${ }^{2}$, Samidha Worah², Jill A White ${ }^{1}$, Rene Luna ${ }^{1}$, \\ Tsung-Teh $\mathrm{Wu}^{1}$, Stanley R Hamilton ${ }^{1}$ and Asif Rashid ${ }^{1}$ \\ ${ }^{1}$ Department of Pathology, The University of Texas MD Anderson Cancer Center, Houston, TX, USA \\ and ${ }^{2}$ Department of Gastrointestinal Oncology, The University of Texas MD Anderson Cancer Center, \\ Houston, TX, USA
}

\begin{abstract}
Carcinoid tumors and pancreatic endocrine tumors are uncommon neuroendocrine neoplasms, and their genetic alterations are not well characterized. These tumors have site-specific differences in neuroendocrine characteristics, clinical course and genetic alterations. We compared clinicopathological features and loss of heterozygosity of chromosomes 11q, 16q and 18, and BRAF gene mutations in 47 patients with neuroendocrine tumors including 16 with pancreatic endocrine tumors, 15 with nonileal carcinoid tumors and 16 with ileal carcinoid tumors. Patients with carcinoid tumors had more frequent history of alcohol consumption compared to patients with pancreatic endocrine tumors $(P=0.02)$, and patients with ileal carcinoid tumors more frequently had liver metastasis compared to patients with nonileal carcinoid tumors and pancreatic endocrine tumors $(P=0.02)$. Allelic loss of chromosome 11q was present in $21 \%$ of tumors, chromosome $16 q$ in $13 \%$, and chromosome 18 in $30 \%$. These alterations differed with the anatomical subsite of tumor: allelic loss of chromosome 18 was present in $69 \%$ of ileal carcinoid tumors, $13 \%$ of nonileal carcinoid tumors and $6 \%$ of pancreatic endocrine tumors $(P=0.001)$. In contrast to pancreatic endocrine tumors and nonileal carcinoid tumors, all 11 ileal tumors with loss of chromosome 18 had complete loss of both chromosomal arms. No BRAF mutations were identified. Complete allelic loss of chromosome 18 was associated with smaller tumor size $(P=0.02)$. Our study indicates that genetic alterations vary by tumor subsite and clinicopathologic features, and ileal carcinoid tumors have distinctive clinicopathologic and genetic profiles.
\end{abstract}

Modern Pathology (2005) 18, 1079-1087. doi:10.1038/modpathol.3800389; published online 6 May 2005

Keywords: allelic loss; BRAF mutations; carcinoid tumor; pancreatic endocrine tumor

Pancreatic endocrine tumors and carcinoid tumors are both rare, indolent neuroendocrine neoplasms with an age-adjusted annual incidence of 2.5-4.5 per $100000 .^{1,2}$ Neuroendocrine tumors are divided by their embryological site of origin into foregut carcinoid tumors, comprising tumors from the lung, stomach, duodenum and pancreas; midgut carcinoid tumors, comprising tumors from the jejunum, ileum, appendix and right colon; and hindgut carcinoid tumors, comprising tumors from the left colon and rectum. Tumors originating from the midgut are most common, with the majority located in the ileum. ${ }^{1,2}$ However, there is heterogeneity

Correspondence: Dr A Rashid, MD, PhD, Department of Pathology, Box 85, The University of Texas MD Anderson Cancer Center, 1515 Holcombe Blvd., Houston, TX 77030, USA.

E-mail: arashid@mdacc.tmc.edu

Received 15 September 2004; revised and accepted 11 January 2005; published online 6 May 2005 among the neuroendocrine tumors of various subsites, including clinicopathologic features, behavior and genetic alterations. For example, the majority of appendiceal carcinoid tumors have benign clinical behavior, but the majority of ileal carcinoid tumors have metastasis at presentation.

The molecular pathogenesis of pancreatic endocrine tumor and carcinoid tumor is poorly understood. ${ }^{3}$ Multiple endocrine neoplasia type-1 (MEN1) is an autosomal dominantly inherited disorder characterized by the development of multiple endocrine tumors including pancreatic endocrine tumors. ${ }^{4}$ MEN1 results from germline mutations of $M E N 1$, a 10-exon gene located on chromosome $11 q 13$ that encodes for menin, a 610-amino-acid protein..$^{3,5-8}$ Recent studies suggest menin regulates the transcription of multiple differentiation-regulating genes in association with a histone methyltransferase complex. ${ }^{9}$ Mutations of the MEN1 gene and allelic loss of chromosome 11q13 are reported in 
sporadic carcinoid tumors and sporadic pancreatic endocrine tumors. ${ }^{10}$

Recent advances have been made in characterization of molecular events underlying the tumorigenesis of carcinoid tumors. Allelic loss of chromosomes 11q, $16 q$ and $18 q$ is reported in typical midgut carcinoids. ${ }^{3,11-14}$ Allelic loss of chromosome $18 \mathrm{q}$ is frequent in colorectal carcinomas. ${ }^{15}$ DPC4 (Smad4) gene, present on chromosome 18q, has mutations in about $50 \%$ of pancreatic ${ }^{16}$ and in about $20 \%$ of colorectal carcinomas. ${ }^{17}$

The RAS-RAF-MEK (mitogen-activated protein/ extracellular signal-regulated kinase kinase)-ERK (extracellular signal-regulated kinase)-MAP (mitogen-activated protein) kinase pathway mediates cellular responses to growth signals. BRAF mutations have been found in a variety of human cancers including colorectal carcinomas. ${ }^{18}$ Mutations in $B R A F$ gene occur in two regions of the BRAF kinase domain, that is, the activation segment that protects the substrate binding site, and less commonly, the $G$ loop that mediates binding of ATP. Previous studies have shown that carcinoid tumors or pancreatic endocrine tumors lack alterations of KRAS and p53 genes, ${ }^{5,19}$ but BRAF mutations have not been reported.

In the present study, we studied pancreatic endocrine tumors and carcinoid tumors for allelic loss of chromosomes 11q, 16q and 18, and BRAF gene mutations, and associated the genetic alterations with clinicopathologic features.

\section{Materials and methods}

\section{Characteristics of Specimens and Patients}

Frozen tumor and non-neoplastic tissue were obtained from surgical specimens of patients undergoing resections for pancreatic endocrine tumors or carcinoid tumors in the frozen section laboratory of the Department of Pathology, The University of Texas MD Anderson Cancer Center. The MD Anderson Cancer Center Surveillance Committee (institutional review board) approved this study. The patient records and histopathological findings were reviewed. The histopathology was reviewed and the tumors were classified as pancreatic endocrine tumors and carcinoid tumors using established criteria. $^{20,21}$ There were 16 pancreatic endocrine tumors, 29 carcinoid tumors, and two pulmonary atypical carcinoid tumors (Figure 1). In total, 16 of the carcinoid tumors were in the ileum. The nonileal carcinoid tumors included five pulmonary, three gastric, two duodenal, one appendiceal, three cecal and one rectal tumor. Immunohistochemistry was performed by using standard techniques including antigen retrieval as described previously, ${ }^{22}$ using mouse monoclonal antibodies to chromogranin A (1:4000 dilution, Chemicon International, Temecula, CA, USA) and synaptophysin (1:4000 dilution, Chemicon International, Temecula, CA,
USA), and polyclonal antibodies to gastrin (prediluted, DakoCytomation, Inc., Carpinteria, CA, USA), glucagon (1:2000 dilution, DiaSorin, Inc., Stillwater, MN, USA), insulin (1:100 dilution, DakoCytomation, Inc.), pancreatic polypeptide (1:600 dilution, DakoCytomation, Inc.), somatostatin (1:500 dilution, DakoCytomation, Inc.) and vasoactive intestinal peptide (1:75 dilution, Bachem Biosciences, Inc., King Prussia, PA, USA). The functional status of tumors was ascertained by serum measurements of hormones and/or clinical syndrome due to hormonal hypersecretion.

\section{DNA Extraction}

DNA from both tumor and normal tissue were microdissected and extracted from fresh-frozen specimens using a commercial kit (Qiagen DNA extraction kit, Qiagen, Inc., Valencia, CA, USA), after reviewing a hematoxylin and eosin-stained slide from a frozen block. The neoplastic cellularity was at least $70 \%$. Tumor samples were taken from the primary site of tumor in all but four tumors (three ileal carcinoid tumors and a cecal carcinoid tumor) that were harvested from the liver metastasis.

\section{Loss of Heterozygosity of Chromosomes 11q, 16q and 18}

Loss of heterozygosity of chromosomes 11q, 16q and 18 was determined using 5,5 and 27 dinucleotide microsatellite markers, respectively (Figure 1). Loss of heterozygosity was determined by PCR amplification using fluorescent dye-labeled (6-FAM, NED or VIC) and unlabeled primers (Applied Biosystems, Foster City, CA, USA or Invitrogen, Carlsbad, CA, USA). PCR was performed in $15 \mu \mathrm{l}$ reaction volumes containing $20 \mathrm{ng}$ of DNA, $9 \mu \mathrm{l}$ ABI Prism ${ }^{\mathbb{R}}$ True Allele $^{\mathrm{TM}}$ PCR Premix (Applied Biosystems), and 5 pmol of each primer. The cycling conditions were denaturation at $95^{\circ} \mathrm{C}$ for $12 \mathrm{~min}, 10$ cycles $\left(94^{\circ} \mathrm{C}\right.$ for $15 \mathrm{~s}, 55^{\circ} \mathrm{C}$ for $15 \mathrm{~s}, 72^{\circ} \mathrm{C}$ for $\left.30 \mathrm{~s}\right), 32$ cycles $\left(89^{\circ} \mathrm{C}\right.$ for $15 \mathrm{~s}, 55^{\circ} \mathrm{C}$ for $15 \mathrm{~s}, 72^{\circ} \mathrm{C}$ for $30 \mathrm{~s}$ ), and extension at $72^{\circ} \mathrm{C}$ for $10 \mathrm{~min}$. A $0.25 \mu \mathrm{l}$ aliquot of each PCR product was combined with $12 \mu \mathrm{l}$ of formamide and $0.5 \mu \mathrm{l}$ of GENESCAN ${ }^{\circledR}$ 400HD [ROX] size standard (Applied Biosystems). The samples were then subjected to capillary electrophoresis on an Applied Biosystems 3730 DNA Analyzer. Loss of a marker was considered to be present when the assay showed absence or decrease in intensity by more than $50 \%$ of one of two alleles from a tumor sample as compared with the paired control non-neoplastic tissue (examples in Figure 2). Loss of heterozygosity of chromosomal arms was defined by allelic loss of one or more polymorphic (informative) microsatellite markers present on that chromosomal arm. Loss of chromosome 11q using five markers, 16q using five markers, and $18 \mathrm{q}$ using eight markers has been previously reported for 12 tumors, ${ }^{22}$ but all 

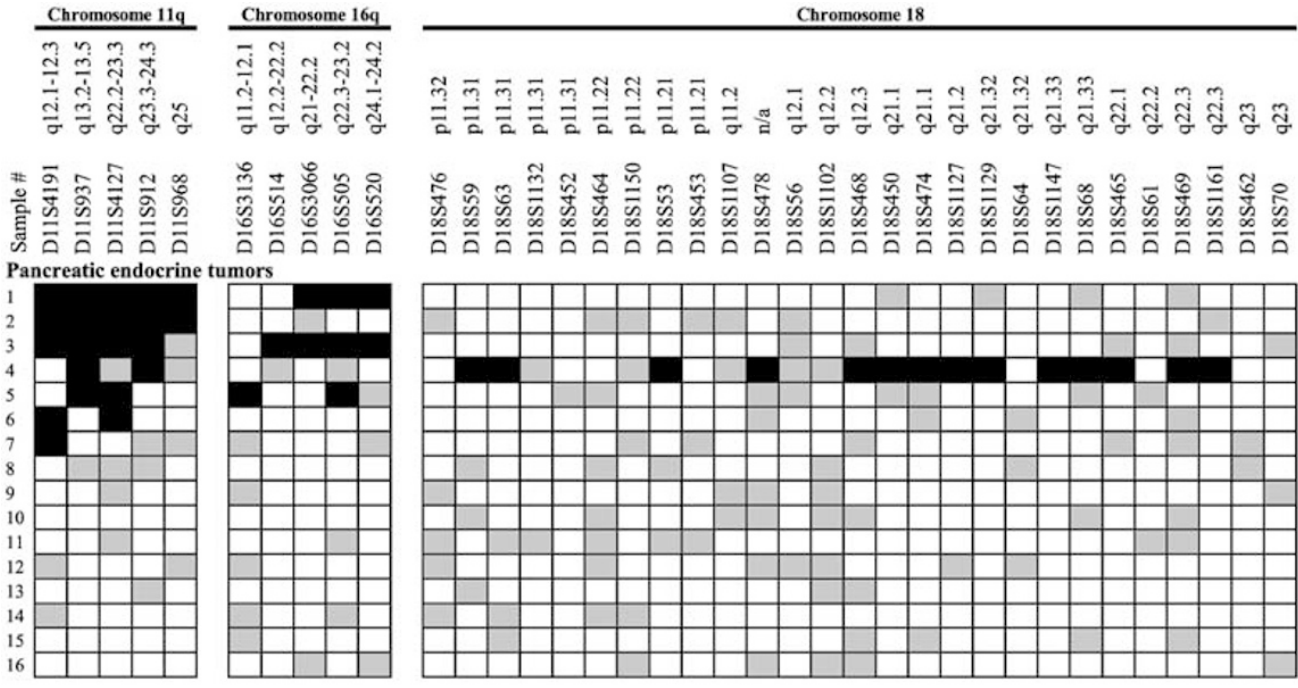

Immunochemistry
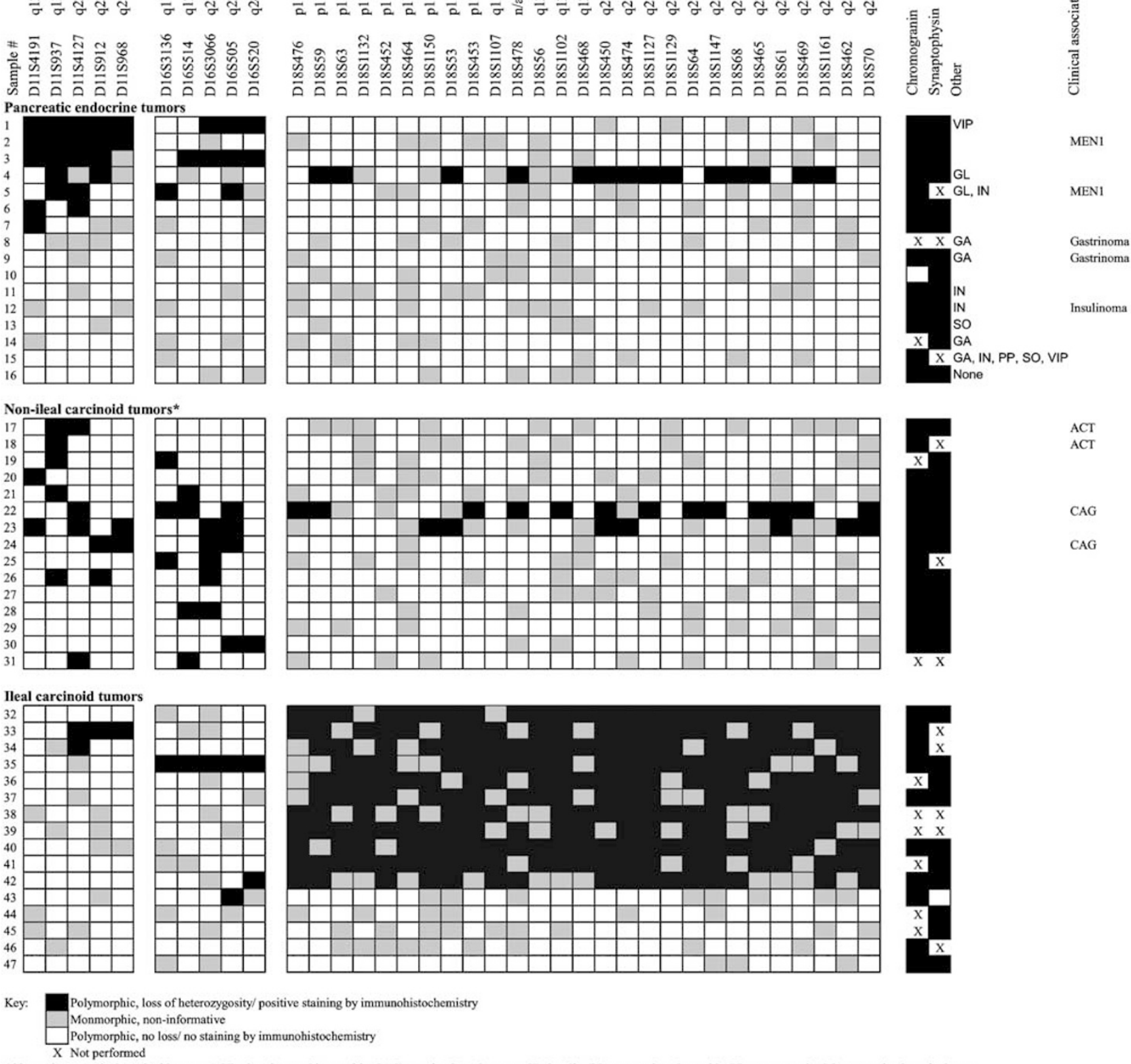

Key: Polymorphic, loss of heterozygosity/ positive staining by immunohistochemistry Monmorphic, non-informative

Monmorphic, non-informative
Polymorphic, no loss/ no staining by immunohistochemistry

$\mathrm{X}$ Not performed

Abbrevations: atypical carcinoid tumor, ACT; chronic atrophic gastritis, CAG; gastrin, GA; glucagon, GL; insulin, IN; pancreatic polypeptide, PP; somatostatin, SO, vasoactive intestinal pep - Site of non-ileal carcinoid tumors: \#17-21, lung; \#22-24, stomach; \#25 and 26, duodenum; \#27, appendix; \#28-30, colon (cecum); and \#31, rectum.

Figure 1 Immunohistochemistry profile, clinical associations, and loss of chromosomes 11q, 16q and 18 in pancreatic endocrine tumors, and nonileal and ileal carcinoid tumors.

chromosome 18 markers were repeated using microdissected DNA. Previously characterized colon carcinoma samples with loss of chromosome 18q were used as positive control and nontumor DNA from the same patient was used as negative control.

\section{Sequencing of BRAF Gene}

Exons 11 and 15 of the BRAF gene were amplified and sequenced as previously described. ${ }^{23}$ Exons 11 and 15 were amplified by genomic PCR using intronic primers and a commercial DNA sequencing kit according to the manufacturer's instructions (BigDye Terminator version 1.1 Cycle Sequencing Kit, Applied Biosystems, Foster City, CA, USA). The PCR products were analyzed with an Applied Biosystems 3730 automated sequencer using forward and reverse primers. A previously characterized colon carcinoma sample with a $B R A F$ mutation was used as positive control and PCR amplification buffer without DNA was used as negative control. 


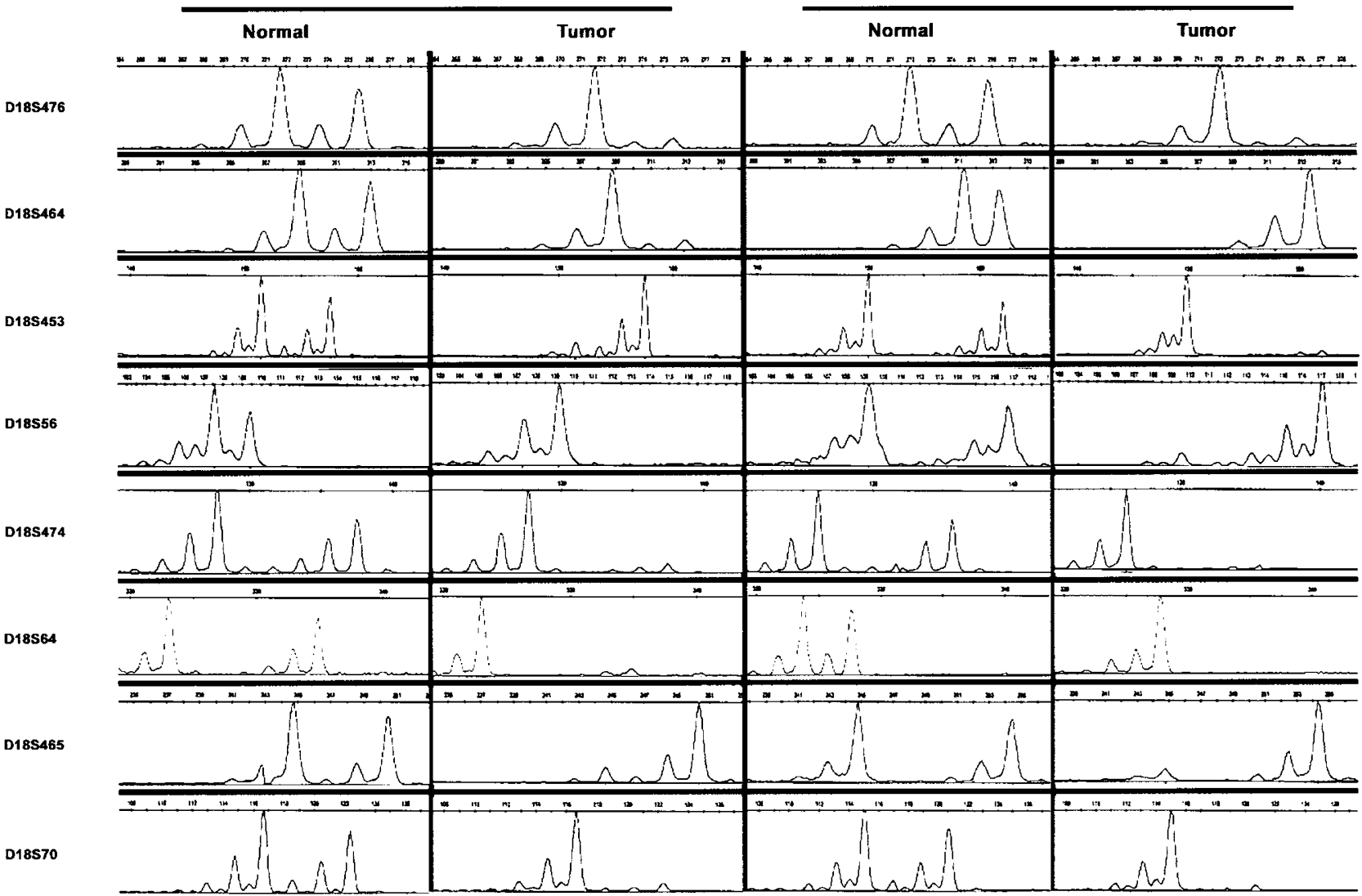

Figure 2 Chromosome 18 loss by PCR amplification using fluorescent primers in two representative neuroendocrine tumors for each marker. PCR was performed using non-neoplastic DNA and tumor DNA. The markers are indicated on the left. Allelic loss is present in the neuroendocrine tumor samples in all panels.

\section{Statistical Analysis}

All statistical analysis was performed using SPSS (SPSS, Inc., Chicago, IL, USA). Comparisons of categorical variables were made using $\chi^{2}$ and Fisher's exact test. Continuous data, including age of diagnosis and tumor size, were evaluated by Student's $t$-test and one-way ANOVA.

\section{Results}

\section{Clinicopathologic Features}

The clinicopathologic features of the 16 patients with pancreatic endocrine tumors, 15 with nonileal carcinoid tumors and 16 with ileal carcinoid tumors are compared in Table 1. History of alcohol consumption was present in $60 \%$ of patients with nonileal carcinoid tumors and $44 \%$ of patients with ileal carcinoid tumors compared to $13 \%$ of patients with pancreatic endocrine tumors $(P=0.02)$. Liver metastasis was present in $69 \%$ of patients with ileal carcinoid tumors compared to $27 \%$ with nonileal carcinod tumors and $25 \%$ with pancreatic endocrine tumors $(P=0.02)$. Age, gender, size of tumor, history of smoking, and vital status were not statistically different among the three groups.

Expression for chromogranin or synaptophysin was present in all 44 tumors evaluated by immunohistochemical staining. Staining for chromogranin was present in $97 \%(37 / 38)$ of tumors and for synaptophysin in $97 \%(36 / 37)$ of tumors. A total of 11 pancreatic endocrine tumors were evaluated by immunohistochemical staining for pancreatic hormones. Three tumors had staining for gastrin, two for insulin, one each for glucagon, somatostatin, vasoactive intestinal peptide, one for insulin and glucagon, one for glucagon, insulin, pancreatic polypeptide, somatostatin and vasoactive intestinal peptide, and one tumor had no staining for any pancreatic hormones. There were two gastrinomas and one insulinoma ascertained by serum measurements of hormones (Figure 1).

\section{Allelic Loss of Chromosomes 11q, 16q and 18}

Allelic loss of chromosome 11q was present in 21\% $(10 / 47)$ of tumors, chromosome $16 \mathrm{q}$ in $13 \%$ (6/47), and chromosome 18 in 30\% (14/47) (Figure 1 and Table 2). Allelic loss of chromosome 11q was 
Table 1 Clinicopathologic features of patients with pancreatic endocrine, and nonileal and ileal carcinoid tumors

\begin{tabular}{|c|c|c|c|c|}
\hline Clinicopathologic features & $\begin{array}{c}\text { Pancreatic endocrine } \\
\text { tumors }(\mathrm{n}=16)\end{array}$ & $\begin{array}{l}\text { Nonileal carcinoid } \\
\text { tumors }(\mathrm{n}=15)\end{array}$ & $\begin{array}{l}\text { Ileal carcinoid tumors } \\
\qquad(\mathrm{n}=16)\end{array}$ & P-value \\
\hline Age (mean \pm s.d.) (years) & $56.1 \pm 15.9$ & $59.5 \pm 11.0$ & $59.0 \pm 13.2$ & $\mathrm{NS}^{\mathrm{b}}$ \\
\hline \multicolumn{5}{|l|}{ Gender } \\
\hline Female & $56(9)$ & $53(8)$ & $44(7)$ & \multirow[t]{2}{*}{ NS } \\
\hline Male & $44(7)$ & $47(7)$ & $56(9)$ & \\
\hline \multicolumn{5}{|l|}{ History of smoking } \\
\hline Current or former & $56(9)$ & $67(10)$ & $38(6)$ & \multirow[t]{2}{*}{ NS } \\
\hline Never & $44(7)$ & $33(5)$ & $62(10)$ & \\
\hline \multicolumn{5}{|c|}{ History of alcohol consumption } \\
\hline Current or former & $13(2)$ & $60(9)$ & $44(7)$ & \multirow[t]{2}{*}{$0.02^{\mathrm{c}}$} \\
\hline Never & $87(14)$ & $40(6)$ & $56(9)$ & \\
\hline $\begin{array}{l}\text { Size of primary tumor } \\
(\text { mean } \pm \text { s.d.) }(\mathrm{cm})\end{array}$ & $4.1 \pm 2.7$ & $3.3 \pm 5.9$ & $2.1 \pm 1.0$ & NS \\
\hline \multicolumn{5}{|l|}{ Lymph node metastasis } \\
\hline Present & $44(7)$ & $53(8)$ & $87(12)$ & \multirow[t]{2}{*}{ NS } \\
\hline Absent & $56(9)$ & $47(7)$ & $13(4)$ & \\
\hline \multicolumn{5}{|l|}{ Liver metastasis } \\
\hline Present & $25(4)$ & $27(4)$ & $69(11)$ & \multirow[t]{2}{*}{$0.02^{\mathrm{d}}$} \\
\hline Absent & $75(12)$ & $73(11)$ & $31(5)$ & \\
\hline \multicolumn{5}{|l|}{ Vital status } \\
\hline Alive & $87(14)$ & $87(13)$ & $100(16)$ & \multirow[t]{2}{*}{ NS } \\
\hline Dead & $13(2)$ & $13(2)$ & $0(0)$ & \\
\hline
\end{tabular}

Values are expressed as percent and numbers in parentheses.

${ }^{\mathrm{a}}$ Comparison among all three groups.

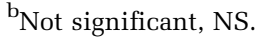

${ }^{\mathrm{C}}$ Pancreatic endocrine tumors vs carcinoid tumors, $P=0.01$ for ethanol consumption.

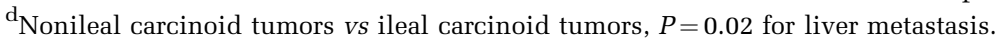

Table 2 Summary of loss of heterozygosity of chromosomes 11q, 16q and 18, and BRAF mutations in pancreatic endocrine tumors, nonileal carcinoid tumors and ileal carcinoid tumors

\begin{tabular}{lcccc}
\hline Alteration & $\begin{array}{c}\text { Pancreatic endocrine } \\
\text { tumors }(\mathrm{n}=16)\end{array}$ & $\begin{array}{c}\text { Non-ileal carcinoid } \\
\text { tumors (n=15) }\end{array}$ & $\begin{array}{c}\text { Ileal carcinoid tumors } \\
(\mathrm{n}=16)\end{array}$ & P-value $^{\mathrm{a}}$ \\
\hline Loss of chromosome 11q & $38(6)$ & $13(2)$ & $13(2)$ & $19(3)$ \\
Loss of chromosome 16q & $19(3)$ & $0(0)$ & $69(11)$ & $\mathrm{NS}^{\mathrm{b}}$ \\
Loss of chromosome 18, any loss & $6(1)$ & $13(2)$ & $69(11)$ & $\mathrm{NS}^{\mathrm{c}}$ \\
$\begin{array}{l}\text { Loss of chromosome 18, } \\
\text { complete loss }\end{array}$ & $0(0)$ & $0(0)$ & $0(0)$ & $0.001^{\mathrm{c}}$ \\
$B R A F$ mutations & $0(0)$ & $0(0)$ & $\mathrm{NS}$ \\
\hline
\end{tabular}

Values are expressed as percent and numbers in parentheses.

${ }^{\mathrm{a} C}$ Comparison among all three groups.

${ }^{\mathrm{b}}$ Not significant, NS.

${ }^{\mathrm{c}}$ Pancreatic endocrine tumors vs carcinoid tumors, $P=0.01$ for any loss of chromosome 18 , and $P=0.006$ for complete loss of chromosome 18

present in $38 \%$ of pancreatic endocrine tumors, $13 \%$ of nonileal carcinoid tumors, and $13 \%$ of ileal carcinoid tumors (not significant). Allelic loss of chromosome $16 q$ was present in $19 \%$ of pancreatic endocrine tumors, $0 \%$ of nonileal carcinoid tumors, and $19 \%$ of nonileal carcinoid tumors (not significant). By contrast, allelic loss of chromosome 18 was present in $69 \%$ of ileal carcinoid tumors compared to only $13 \%$ in nonileal carcinoid tumors and $6 \%$ in pancreatic endocrine tumors $(P=0.001)$. In all 11 ileal carcinoid tumors with loss of chromosome 18, all polymorphic markers on the short arm (p) and long arm (q) of chromosome 18 showed loss, compared to none of nonileal carcinoid tumors or 
pancreatic endocrine tumors $(P=0.001$, Figure 1$)$. Of note, nonileal carcinoid tumors were comprised of small number of tumors from multiple sites.

\section{BRAF Mutations}

No BRAF gene mutations were present in any carcinoid tumor or pancreatic endocrine tumor.

\section{Genetic Alterations and Clinicopathologic Features}

Associations of chromosome 18 loss status and clinicopathologic features are compared in Table 3. The size of tumors was associated with allelic loss of chromosome 18: the mean size of tumors with complete loss of chromosome 18 was $2.2 \pm 0.7 \mathrm{~cm}$ compared to $8.7 \pm 12.8 \mathrm{~cm}$ for tumors with partial loss of chromosome 18 and $3.4 \pm 2.4 \mathrm{~cm}$ for tumors with no loss of chromosome $18(\bar{P}=0.02)$. There was no association between the genetic alterations and immunohistochemical staining for hormones.

\section{Discussion}

In our study, we found loss of chromosome 11q in pancreatic endocrine tumors and occasional loss in ileal carcinoid tumors and one atypical carcinoid tumor of lung. The long arm of chromosome 11 is a gene-rich region but contains only a few known or putative tumor suppressor genes, ${ }^{24} 11 \mathrm{q} 13$ includes MEN1, succinate-ubiquinone oxireductase subunit $D$ and PGL2 genes, and 11q22-q23 includes PGL1 and PPP2R1B (serine/threonine protein phosphatase subunit locus) genes. Allelic loss of more distal chromosomal regions located at 11q25 was identified in breast and ovarian cancer. ${ }^{24}$ In previous reports, allelic loss of $11 \mathrm{q}$ was identified in pancreatic endocrine tumors, and ileal and lung carcinoid tumors but was not found in any appendiceal or rectal carcinoid tumors. ${ }^{14,25-27}$ Another study reported a high frequency of allelic loss at $11 q 13$ locus (62\%) in midgut carcinoid tumors, but a low frequency of succinate-ubiquinone oxireductase subunit $D$ gene mutations, suggesting that other tumor suppressor genes may be targets for allelic loss at this region. ${ }^{28}$

In our study, pancreatic endocrine tumors and carcinoid tumors demonstrated occasional loss of chromosome $16 \mathrm{q}$ with loss of loci at 16q11.2-q24.2. This chromosomal region harbors two putative tumor suppressor genes: CTCF (CCCTC-binding factor) gene, a transcriptional repressor of c-myc; and the E-cadherin/CDH1 gene involved in celladhesion. Reduced expression of E-cadherin by

Table 3 Chromosome 18 loss in pancreatic endocrine tumors, nonileal and ileal carcinoid tumors and clinicopathologic associations

\begin{tabular}{|c|c|c|c|c|}
\hline \multirow[t]{2}{*}{ Clinicopathologic features } & \multicolumn{3}{|c|}{ Chromosome 18 status } & \multirow[t]{2}{*}{$P$-value } \\
\hline & No loss $(\mathrm{n}=33)$ & Partial loss $(\mathrm{n}=3)$ & Complete loss $(\mathrm{n}=11)$ & \\
\hline Age (mean \pm s.d.) (years) & $56.1 \pm 13.3$ & $65.3 \pm 12.9$ & $62.6 \pm 13.1$ & $\mathrm{NS}^{\mathrm{b}}$ \\
\hline \multicolumn{5}{|l|}{ Gender } \\
\hline Female & $55(18)$ & $33(1)$ & $45(5)$ & \multirow[t]{2}{*}{ NS } \\
\hline Male & $45(15)$ & $67(2)$ & $55(6)$ & \\
\hline \multicolumn{5}{|l|}{ History of smoking } \\
\hline Current or former & $58(19)$ & $67(2)$ & $36(4)$ & \multirow[t]{2}{*}{ NS } \\
\hline Never & $42(14)$ & $33(1)$ & $64(7)$ & \\
\hline \multicolumn{5}{|l|}{ History of alcohol consumption } \\
\hline Current or former & $33(11)$ & $67(2)$ & $45(5)$ & \multirow[t]{2}{*}{ NS } \\
\hline Never & $67(22)$ & $33(1)$ & $55(6)$ & \\
\hline Size of primary tumor (mean \pm s.d.) $(\mathrm{cm})$ & $3.4 \pm 2.4$ & $8.7 \pm 12.8$ & $2.2 \pm 0.7$ & 0.02 \\
\hline \multicolumn{5}{|l|}{ Lymph node metastasis } \\
\hline Present & $55(18)$ & $33(1)$ & $73(8)$ & \multirow[t]{2}{*}{ NS } \\
\hline Absent & $45(15)$ & $67(2)$ & $27(3)$ & \\
\hline \multicolumn{5}{|l|}{ Liver metastasis } \\
\hline Present & $36(12)$ & $33(1)$ & $55(6)$ & \multirow{2}{*}{ NS } \\
\hline Absent & $64(21)$ & $67(2)$ & $45(5)$ & \\
\hline \multicolumn{5}{|l|}{ Vital status } \\
\hline Alive & $91(30)$ & $67(2)$ & $100(11)$ & \multirow[t]{2}{*}{ NS } \\
\hline Dead & $9(3)$ & $33(1)$ & $0(0)$ & \\
\hline
\end{tabular}

Values are expressed as percent and numbers in parentheses.

${ }^{\mathrm{a} C o m p a r i s o n}$ among all three groups.

${ }^{\mathrm{b}}$ Not significant, NS. 
immunohistochemical analyses has been correlated with malignant behavior among patients with gastrointestinal carcinoid tumors. ${ }^{29}$ Homozygous loss of function of CTCF gene by tumor-specific rearrangements has been identified in breast carcinomas. ${ }^{30,31}$ Interestingly, reported allelic loss of 16q21-qter in metastatic midgut carcinoid tumors but not in primary carcinoid tumors suggests that putative tumor suppressor genes mapped at this locus may be involved in tumor progression. ${ }^{14}$

In our study, we identified frequent complete loss of chromosome 18 in ileal carcinoid tumors compared to pancreatic endocrine tumors and nonileal carcinoid tumors. Chromosome 18 loss in midgut carcinoid tumors has been previously reported. ${ }^{3,13,14,32}$ Interestingly, a higher frequency of allelic loss of $18 \mathrm{q}$ was reported for classical midgut carcinoids $^{14,32}$ but not for lung carcinoid tumors. ${ }^{13,27}$ In our study, the high frequency of loss of the entire chromosome 18 in ileal carcinoid tumors suggest that there are multiple tumor suppressor genes in chromosome 18 involving both the short and the long arms that play an important role in the tumorigenesis of ileal carcinoid tumors. Among the tumor suppressor genes harbored on chromosome $18 \mathrm{q}$, the most extensively studied are the $D C C$ gene localized at 18q21.2 and the DPC4 (Smad4) gene localized at 18q21.1. Inactivation of chromosome $18 \mathrm{q}$ is identified not only in colorectal carcinoma, ${ }^{33}$ but also in pancreatic,${ }^{34}$ gastric,${ }^{35}$ small intestinal, ${ }^{36}$ appendiceal, ${ }^{37}$ breast, ${ }^{38}$ prostatic $^{39}$ and squamous cell carcinomas. ${ }^{40,41}$ DPC4 (Smad4) gene inactivation is present in pancreatic, ${ }^{34}$ small intestinal $^{36}$ and appendiceal carcinomas, ${ }^{37}$ but is uncommon in other malignancies. ${ }^{42,43}$ Data from the present study and the previous studies show that chromosome $18 \mathrm{q}$ loss is infrequent in pancreatic endocrine tumors ${ }^{44}$ but common in midgut carcinoid tumors ${ }^{32}$ and goblet cell carcinoid tumors of appendix. ${ }^{22}$ However, these tumors lack DPC4 gene mutations or loss of DPC4 protein expression suggesting that DPC4 gene is not the target of this chromosomal loss. Loss of heterozygosity of chromosome 18q was a frequent event associated with poor prognosis in pancreatic adenocarcinomas, and restoration of chromosome 18 reduced the tumorigenicity. ${ }^{45}$ Allelic loss at $18 \mathrm{q} 12.3-\mathrm{q} 23$ was reportedly common in squamous cell carcinoma but not in solar keratoses. ${ }^{40}$ Also, loss of chromosome18p may be associated with adverse clinical outcome in patients with high-risk breast cancer. ${ }^{46}$ Other putative tumor suppressor genes localized immediately telomeric to DCC and DPC4 at microsatellite locus 18q21.3 are serpins (Serine Proteinase Inhibitors) some of which (maspin) reportedly can suppress tumor growth and spread in breast carcinoma. ${ }^{47}$ Loss of cables, a novel cyclin-dependent kinase interacting protein, which maps to human chromosome $18 q 11$ has been associated with ovarian cancer. ${ }^{48}$

In our study, no BRAF mutation was present in pancreatic endocrine tumors or carcinoid tumors.
Previous studies have shown that carcinoid tumors or pancreatic endocrine tumors lack KRAS mutations, ${ }^{5,19}$ but have methylation of RASSF1A gene in pancreatic endocrine tumors ${ }^{49}$ and lung carcinoid tumors. ${ }^{50}$

Our study demonstrated that alcohol consumption was more common in carcinoid tumors and compared to pancreatic endocrine tumors, and ileal carcinoid tumors had frequent loss of the entire chromosome 18. However, a limitation of our study is that the nonileal carcinoid tumors are comprised of small number of tumors from multiple sites. Several molecular differences among pancreatic endocrine tumors, and ileal and nonileal carcinoid tumors have been previously reported. ${ }^{3}$ Although ileal and nonileal carcinoid tumor and pancreatic endocrine tumor share a number of similarities, it is important that these groups of tumors continue to be analyzed separately rather than considered in combined series. Not only are these three general groups of tumors functionally different, but they also may differ in biologic behavior in terms of metastatic spread and aggressiveness.

In conclusion, the loss of chromosomes 11q, 16q and 18 identified in the majority of these tumors suggests that putative or yet unknown tumor suppressor genes may have a major role in the pathogenesis of ileal and nonileal carcinoid tumors and pancreatic endocrine tumors. The findings in our study further support the concept that these three groups of tumor are fundamentally different and the tumorigenic process evolves along at least two different pathways.

\section{Acknowledgements}

This study was supported by a grant to AR and JCY from Dr and Mrs Raymond and Beverly Sackler and Verto Institute, Stamford, CT.

\section{References}

1 Modlin IM, Lye KD, Kidd M. A 5-decade analysis of 13,715 carcinoid tumors. Cancer 2003;97:934-959.

2 Maggard MA, O’Connell JB, Ko CY. Updated population-based review of carcinoid tumors. Ann Surg 2004; 240:117-122.

3 Jensen RT. Carcinoid and pancreatic tumors: recent advances in molecular pathogenesis, localization, and treatment. Curr Opin Oncol 2000;12:368-377.

4 Marx SJ. Multiple endocrine neoplasia type 1: clinical and genetic features of the hereditary endocrine neoplasias. Recent Prog Horm Res 1999;54:397-438.

5 Rindi G, Candusso ME, Solcia E. Molecular aspects of the endocrine tumors of the pancreas and the gastrointestinal tract. Ital J Gastroenterol Hepatol 1999; 31(Suppl 2):S135-S138.

6 Rindi G, Capella C, Solcia E. Recent advances in the pathophysiology and management of inflammatory bowel diseases and digestive endocrine tumors. In: 
Mignon M, Colombel JF (eds). Pathobiology and Classification of Gut Endocrine Tumors. John Libbey Eurotext Publishing: Paris, 1999, pp 177-191.

7 Calender A. Recent advances in the pathophysiology and management of inflammatory bowel diseases and digestive endocrine tumors. In: Mignon M, Colombel JF (eds). New Insights in Genetics of Digestive Neuroendocrine Tumors. John Libbey Eurotext Publishing: Paris, 1999, pp 155-161.

8 Chandrasekharappa SC, Guru SC, Manickam P, et al. Positional cloning of the gene for multiple endocrine neoplasia-type 1. Science 1997;276:404-407.

9 Hughes CM, Rozenblatt-Rosen O, Milne TA, et al. Menin associates with a trithorax family histone methyltransferase complex and with the hoxc8 locus. Mol Cell 2004;13:587-597.

10 Görtz B, Roth J, Krähenmann A, et al. Mutations and allelic deletions of the MEN1 gene are associated with a subset of sporadic endocrine pancreatic and neuroendocrine tumors and not restricted to foregut neoplasms. Am J Pathol 1999;154:429-436.

11 Jakobovitz O, Nass D, DeMarco L, et al. Carcinoid tumors frequently display genetic abnormalities involving chromosome 11. J Clin Endocrinol Metab 1996; 81:1177-1183.

12 Terris B, Meddeb M, Marchio A, et al. Comparative genomic hybridization analysis of sporadic neuroendocrine tumors of the digestive system. Genes Chromosomes Cancer 1998;22:50-56.

13 Zhao J, de Krijger RR, Meier D, et al. Genomic alterations in well-differentiated gastrointestinal and bronchial neuroendocrine tumors (carcinoid tumors): marked differences indicating diversity in molecular pathogenesis. Am J Pathol 2000;157:1431-1438.

14 Kytölä S, Höög A, Nord B, et al. Comparative genomic hybridization identifies loss of 18q22-qter as an early and specific event in tumorigenesis of midgut carcinoid tumors. Am J Pathol 2001;158:1803-1808.

15 Watanabe T, Wu TT, Catalano PJ, et al. Molecular predictors of survival after adjuvant chemotherapy for colon cancer. N Engl J Med 2001;344:1196-1206.

16 Hahn SA, Schutte M, Hoque AT, et al. DPC4, a candidate tumor suppressor gene at human chromosome 18q21.1. Science 1996;271:350-353.

17 Ohtaki N, Yamaguchi A, Goi T, et al. Somatic alterations of the DPC4 and Madr2 genes in colorectal cancers and relationship to metastasis. Int J Oncol 2001;18:265-270.

18 Davies H, Bignell GR, Cox C, et al. Mutations of the BRAF gene in human cancer. Nature 2002;417: 949-954.

19 Weber HC, Jensen RT. Advances in pancreatic disease: molecular biology, diagnosis and treatment. In: Dervenis CG (ed). Pancreatic Endocrine Tumors and Carcinoid Tumors: Recent Insights from Genetic and Molecular Biologic Studies. Georg Thieme Verlag: New York, NY, 1996, pp 55-75.

20 Klöppel G, Heitz PU, Capella C, et al. Endocrine tumors of the pancreas. In: Solcia E, Klöppel G, Sobin LH (eds). World Health Organization International Histological Classification of Tumors: Histological Typing of Endocrine Tumors, 2nd edn. SpringerVerlag: Berlin, 2000, pp 56-60.

21 Solcia E, Capella C, Klöppel G, et al. Endocrine tumors of the gastrointestinal tract. In: Solcia E, Klöppel G, Sobin LH (eds). World Health Organization International Histological Classification of Tumors: Histologi- cal Typing of Endocrine Tumors, 2nd edn. SpringerVerlag: Berlin, 2000, pp 61-68.

22 Stancu M, Wu T-T, Wallace C, et al. Genetic alterations in goblet cell carcinoid tumors of the vermiform appendix and comparison with gastrointestinal carcinoid tumors. Mod Pathol 2003;16:1189-1198.

23 Chan TL, Zhao W, Leung SY, et al. BRAF and KRAS mutations in colorectal hyperplastic polyps and serrated adenomas. Cancer Res 2003;63:4878-4881.

24 Koreth J, Bakkenist CJ, McGee JO. Chromosomes, 11q and cancer: a review. J Pathol 1999;187:28-38.

25 Rigaud G, Missiaglia E, Moore PS, et al. High resolution allelotype of nonfunctional pancreatic endocrine tumors: identification of two molecular subgroups with clinical implications. Cancer Res 2001; 61:285-292.

26 D’adda T, Pizzi S, Azzoni C, et al. Different patterns of 11q allelic losses in digestive endocrine tumors. Hum Pathol 2002;33:322-329.

27 Walch AK, Zitzelsberger HF, Aubele MM, et al. Typical and atypical carcinoid tumors of the lung are characterized by $11 \mathrm{q}$ deletions as detected by comparative genomic hybridization. Am J Pathol 1998;153: 1089-1098.

28 Kytölä S, Nord B, Elder EE, et al. Alterations of SDHD gene locus in midgut carcinoid tumors, Merkel cell carcinomas, pheochromocytomas, and abdominal paragangliomas. Genes Chromosomes Cancer 2002;34: 325-332.

29 Kawahara M, Kammori M, Kanauchi H, et al. Immunohistochemical prognostic indicators of gastrointestinal carcinoid tumors. Eur J Surg Oncol 2002; 28:140-146.

30 Filippova GN, Lindblom A, Meincke LJ, et al. A widely expressed transcription factor with multiple DNA sequence specificity, CTCF, is localized at chromosome segment 16q22.1 within one of the smallest regions of overlap for common deletions in breast and prostate cancers. Genes Chromosomes Cancer 1998;22: 26-36.

31 Berx G, Cleton-Jansen AM, Nollet F, et al. E-cadherin is a tumor/invasion suppressor gene mutated in human lobular breast cancers. EMBO J 1995;14:6107-6115.

32 Löllgen RM, Hessman O, Szabo E, et al. Chromosome 18 deletions are common events in classical midgut carcinoid tumors. Int J Cancer 2001;92:812-815.

33 Fearon ER, Cho KR, Nigro JM, et al. Identification of a chromosome $18 \mathrm{q}$ gene that is altered in colorectal cancers. Science 1990;247:49-56.

34 Hohne MW, Halatsch ME, Kahl GF, et al. Frequent loss of expression of the potential tumor suppressor gene DCC in ductal pancreatic adenocarcinoma. Cancer Res 1992;52:2616-2619.

35 Uchino S, Tsuda H, Noguchi M, et al. Frequent loss of heterozygosity at the DCC locus in gastric cancer. Cancer Res 1992;52:3099-3102.

36 Bläker H, von Herbay A, Penzel R, et al. Genetics of adenocarcinomas of the small intestine: frequent deletions at chromosome $18 \mathrm{q}$ and mutations of the SMAD4 gene. Oncogene 2002;21:158-164.

37 Maru D, Wu TT, Canada A, et al. Loss of chromosome $18 \mathrm{q}$ and DPC4 (Smad4) mutations in appendiceal adenocarcinomas. Oncogene 2004;23:859-864.

38 Devilee P, van Vliet M, Kuipers-Dijkshoorn N, et al. Somatic genetic changes on chromosome 18 in breast carcinomas: is DCC gene involved? Oncogene 1991;6: 311-315. 
39 Gao X, Honn KV, Grignon D, et al. Frequent loss of expression and loss of heterozygosity of the putative tumor suppressor gene DCC in prostatic carcinomas. Cancer Res 1993;53:2723-2727.

40 Ashton KJ, Weistein SR, Maguire DJ, et al. Chromosomal aberrations in squamous cell carcinoma and solar keratoses revealed by comparative genomic hybridization. Arch Dermatol 2003;139:876-882.

41 Rybicki BA, Savera AT, Gomez JA, et al. Allelic loss and tumor pathology in head and neck squamous cell carcinoma. Mod Pathol 2003;16:970-979.

42 Schutte M, Hruban RH, Hedrick L, et al. DPC4 gene in various tumor types. Cancer Res 1996;56:2527-2530.

43 Powell SM, Harper JC, Hamilton SR, et al. Inactivation of Smad4 in gastric carcinomas. Cancer Res 1997;57: 4221-4224.

44 Perren A, Saremaslani P, Schmid S, et al. DPC4/ Smad4: no mutations, rare allelic imbalances, and retained protein expression in pancreatic endocrine tumors. Diagn Mol Pathol 2003;12:181-186.
45 Lefter LP, Sunamura M, Furukawa T, et al. Inserting chromosome 18 into pancreatic cancer cells switches them to a dormant metastatic phenotype. Clin Cancer Res 2003;9:5044-5052.

46 Climent J, Martinez-Climent JA, Blesa D, et al. Genomic loss of 18p predicts an adverse clinical outcome in patients with high-risk breast cancer. Clin Cancer Res 2002;8:3863-3869.

47 Zou Z, Anisowicz A, Hendricks MJ, et al. Maspin, a serpin with tumor-suppressing activity in human mammary epithelial cells. Science 1994;263:526-529.

48 Dong Q, Kirley S, Rueda B, et al. Loss of cables, a novel gene on chromosome 18q, in ovarian cancer. Mod Pathol 2003;16:863-868.

49 House MG, Herman JG, Guo MZ, et al. Aberrant hypermethylation of tumor suppressor genes in pancreatic endocrine neoplasms. Ann Surg 2003;238:431-432.

50 Toyooka S, Toyooka OK, Maruyama R, et al. DNA methylation profiles of lung tumors. Mol Cancer Ther 2001;1:61-67. 